\title{
GENDER RELATIONS IN THE SPACE OF SCIENCE-FICTION: DUNE (1984)*
}

\author{
Rocío Carrasco Carrasco**
}

\begin{abstract}
Cinema, especially science-fiction, offers various possibilities for the representation of gender relations that, while constructing social identities, reflect contemporary worries and anxieties.

In David Lynch's Dune (1984) gender relations become a means for exploring controversial socio-cultural issues -such as the threat of homosexuality or the plea for gender equalityas well as for understanding the $80 \mathrm{~s}$ attitude towards them. It portrays four clearly differentiated types of societies which are the homes of dissimilar-and sometimes opposedgender relations. Dune's depiction of gender relations hints at the disparity and complicated social reality of the time.
\end{abstract}

Key words: gender relations, science-fiction, patriarchy, homosexuality.

Resumen: El cine, y, más concretamente el de ciencia-ficción, nos ofrece diversas posibilidades para la representación del género. Estas imágenes femeninas o masculinas favorecen a la creación de identidades sociales a la vez que reflejan ansiedades contemporáneas. En Dune de David Lynch (1984) las relaciones genéricas se convierten en un medio para explorar preocupaciones socio-culturales, tales como la amenaza de la homosexualidad o la demanda de igualdad genérica en el contexto de los años 80. En este espacio ficticio encontramos cuatro tipo de sociedades bien diferenciadas en las que las relaciones entre sus miembros se establecen de forma muy diversa. Así Dune nos sugiere la disparidad y complejidad de la sociedad de la época.

Palabras clave: relaciones genéricas, ciencia-ficción, patriarcado, homosexualidad

\section{INTRODUCTION}

It is generally acknowledged that mass-media, especially cinema, offers various possibilities for the representation of gender relations and, in so doing, becomes responsible for the construction of certain social identities. Among all the filmic genres, ScienceFiction $^{1}$ is supposedly a privileged medium for the construction of gender since it allows for hybridisation and for the representation of new and challenging gender traits. In SF movies we find, for example, cyborgs, androgynous characters, aliens, and other

Fecha de recepción: mayo 2004

Fecha de aceptación y versión final: marzo 2005

** Estudiante de doctorado, Departamento de Filología Inglesa, Universidad de Huelva;

$\triangle$ rocicc@yahoo.es.

1 Henceforth SF 
unconventional figures, inhabiting mysterious planets or, more recently, living in cyberspaces and virtual realities.

To this gender construction by means of feminine and masculine images it must be added the power of cinema in reflecting social realities. As paradoxically as it may seem, most SF films, normally set in imaginary places and depicting of non-human beings, are faithful portrayals of contemporary worries and anxieties where dominant ideologies concerning gender relations are normally privileged.

An illustrative example of how the filmic industry both constructs gender and portrays the contemporary North-American reality is the cult movie by David Lynch, Dune (1984). The 80 s conservative ideology is, from my point of view, easily recognised in this fictional space. This ideology is characterised by a return to the kind of morality that had dominated North-American culture before the social upheavals of feminists and other "marginalised" groups that took place in the $60 \mathrm{~s}^{2}$.

At the beginning of Dune we are told that in year 10,191 the Known Universe is formed by four planets - Giedi Prime, Caladan, Kaitain and Arrakis — ruled by the Emperor, who belongs to Kaitain. One of the most important planets is Caladan, led by the Atreides family, whose main leaders are duke Leto Atreides (Jürgen Prochnow) and his son Paul (Kyle McLaghan). This planet, governed by noblemen, clearly contrasts with planet Giedi Prime, which is inhabited by malevolent and vengeful beings, the Harkonnen. Baron Harkonnen (Kenneth McMillan) stands for the main authority of this planet and is responsible for the control of planet Arrakis, which is considered the centre of the universe because it is the only place where the spice known as "melange" exists.

Dune portrays different and challenging gender relationships that become instrumental for the film's meaning and that show at the same time the 80s debate on gender relations. In this article, I will analyse the film's depiction of gender and the cultural implications that the characters' relationships offer. My aim is to show that gender relations in Lynch's Dune serve as the means to explore controversial socio-cultural issues.

Gender critics, especially after the 1970s, agree in affirming the constructed nature of gender and argue that both feminine and masculine traits are defined in every culture in different ways ${ }^{3}$. The tendency of placing women as a biological group rather than as a social one was very common among early second-wave feminists ${ }^{4}$. This essentialist view used to place biological difference as the main cause for women's marginalization and oppression. Women's lack of a penis, they argued, had been associated with the lack of physical strength and their capacity for childbearing, and these inherent traits associated

\footnotetext{
2 Ronald Reagan, elected president in 1981 and re-elected in 1984, became a symbol of this decade, characterised by a turn to the right. Susan Jeffords in her Hard Bodies argues that this president "became the premiere masculine archetype for the $80 \mathrm{~s}$, embodying both national and individual images of manliness that came to underlie the nation's identity during his eight years in office" (Jeffords 1994: 11). ${ }^{3}$ The notion of "gender studies" reached the status of independent discipline in the 1980s. It meant a shift away from the study of women in isolation to the study of women within the context of the social construction of gender, although sometimes it became just a label for women's studies (Peach 1998: 1). ${ }^{4}$ The concept of "gender" suffered a revision due to the activism and scholarship of the 60s and 70s. Thus, they agreed that sex has to do with biology and that accordingly, human beings are classified as male or female, and the traits that defined them fix and constant. On the other hand, gender provides the division into masculine and feminine.
} 
with women had become through history the main reason for arguments affirming women's emotionality, sentimentalism or lack of intelligence. However, at the end of the 70s, when the term "gender" was included in feminist scholarship, many critics adopted a nonessentialist view. Sex difference, they affirmed, does not determine what is to be a man or a woman, but other considerations such as race, ethnic or cultural background, are considered constructors of gender. Sherry B. Ortner in her well-known article "Is Female to Male as Nature is to Culture?" (1972) articulated this distinction between sex and gender, and affirmed that women are universally oppressed and subordinated to men because women are identified with nature and men with culture (Ortner 1995: 493). She argued, however, that there was nothing "essential" in women, this category being a social construct ${ }^{5}$. Ortner's article was later accused of being essentialist, as it took for granted that the subordination of women was a universal condition, found everywhere and at all times.

Once scholars had pointed out the difference between "sex" and "gender", they analysed the importance of gender division for structuring or ordering social life and relationships. The concept of gender as sexual difference, as exposed by de Lauretis in her essay "The Technologies of Gender" (1987), constrains feminist practices within a frame of sex opposition, and the difference among women remains an obstacle difficult, if not impossible, to surmount. Moreover, the notion of sexual difference seems to ignore the fact that a subject is constituted in gender not only by this sexual difference but also by other factors such as class, race, ethnicity, relations, etc (Lauretis 1987: 2). Thus, de Lauretis defines the term 'gender' as 'the product of various social technologies, such as cinema, and of institutionalized discourses, epistemologies, and critical practices, as well as practices of daily life" (Lauretis 1987: 2). She is hereby affirming that the term 'gender' describes accurately those behaviours and traits that are not inherent within the human being but, on the contrary, are socially constructed. She is privileging then, the concept of gender over sex when she analyses social relationships.

Likewise, the traditional concept of masculinity has recently been revised and redefined both by men's studies and by recent film theories on masculinity. Both disciplines agree in denouncing the manipulation of this concept in feminist circles. It is their task, then, to offer new models of masculinity and deconstruct the existent ones. Postmodernism, due to its emphasis on the blurring of frontiers and instability, precludes the abandonment of rigid stereotypes and encourages the adoption of less rigid notions of masculinity.

Thus masculinity, as well as femininity, has been considered as a constructed concept, as it varies depending on the historical time, the culture and the media it is inscribed in. The Reagan Era, in which Dune was released, offers many different representations of masculinity due to its multiple social and cultural changes. Susan Jeffords in Hard Bodies argues in relation to this issue:

The masculine characters that populated some of the decades' most popular Hollywood films offered narratives against which men and women could test, revise, affirm, or negate

\footnotetext{
5 Years later, the critic Judith Butler in Gender Trouble (1990) will affirm that "sex" is not biologically given, but a constructed concept. Thus, at the beginning of her book Bodies that Matter (1993), she takes for granted that "sex" is an ideal construct which is forcibly materialized through time" (Butler 1993: 1).
} 
images of their own conception of masculinity, which because of a changing economy, altering gender relations, increasingly tense race relations, refiguring of U.S. geographic distributions, a technologized militarism, and a reconfigured work force, were themselves in flux throughout this period (Jeffords 1994: 11-12).

She refers to the countless films in the 80 s that conveyed ambivalent and contradictory male characters. Yet, when we find dissimilar representations of the same concept - masculinity - a certain definition normally predominates over others. The prevalent one was offered in great part by the blockbuster films, which became crucial for the delineation of North-American popular culture. These commercial successes coincide in depicting what Jeffords calls "white male action heroes" (Jeffords 1994:12). This highly popularised portrayal of the masculine, linked to hard bodies and endless activity, will offer visual pleasure to mass-audiences and will also help in the construction of US popular culture (Jeffords 1994: 12) ${ }^{6}$.

A striking feature of Dune is its peculiar use of a model of masculinity, embodied mainly by the hero, that does not correspond with the one at work in most popular films of this decade. Paul Atreides differs from those over muscled bodies appearing in action and adventure films, like those of Rambo, Terminator or Rocky, which leads us to consider the film's innovative vision of masculinity. Yet, the "strong militaristic foreign policy position" (Jeffords 1994: 13) that Jeffords clearly associates to the "hard body" is also depicted in the film, but this time by bodies that could rather be linked to the "soft" type. Moreover, the film also coincides with what she considers that "audiences want to see", and offers a narrative "about characters who stand for individualism, liberty, militarism, and mythic heroism" (Jeffords 1994: 16). Dune also represents one of the primary themes of Reaganism, which, according to Jeffords, is the display of the hero in defiance of their governments and institutional bureaucracies (Jeffords 1994: 19). Paul is responsible in the film for the freedom of the oppressed - the Fremen - from their malevolent leaders, and this task constitutes the fulfilment of his messianic condition.

In the four settings represented in the film we find different gender relations which become nevertheless meaningful for the understanding of the 80s attitude towards challenging gender relations. Thus we find two different patriarchal societies, a menacing male world and an unexplored and mysterious planet where gender relations are not very well defined. All these societies are clear allusions of the disparity and complicated social reality of the time. I will analyse next the different types of relationships found in the four planets.

\section{GIEDI PRIME: THE HOME OF MENACING MASCULINITY}

Gender relations within this planet suggest the main social and cultural threats found in North-American society during the 80s. Members of this planet, the Harkonnens, are

\footnotetext{
${ }^{6}$ Yet, these traditional politics did not suit everybody and, as Douglas Brode argues, "[s]uddenly, little movies that hadn't had a chance in competition with the big blockbusters were developing cult followings with the yuppie couples" (Brode 1990: 13). Yuppies' taste, he continues, "tended toward the funky" (Brode 1990: 13).
} 
constantly linked to the filth and their relationships stand for social threats such as AIDS and herpes disease. The fact that all its inhabitants are men narrows the range of relationships in the planet, which are reduced to homosocial ones. Homosexuality stands, therefore, as the only possible model for a relationship that goes beyond friendship or partnership.

Some critics have pointed out the fear of homosexual behaviour in male-dominated spaces, which encourages men to display in an unnatural way all the traditional assumptions linked with masculinity. Àngels Carabí in her essay "Construyendo nuevas masculinidades: Una introducción" noticed this fear of homosexuality especially in closed male spaces. It is, she claims, in contexts like the army, where homosexuality is most feared and the need for "real men" to display a traditional male behaviour becomes more urgent (Carabí 2000: 21$)^{7}$.

However, homosexuality doesn't seem to be a threat for the Harkonnen race but for their adversaries. We find suggestions of homosexual inclinations in some characters. The baron's doctor (Leonardo Cimino) finds an extreme pleasure when he is treating his skin eruptions, spread over his face. Although these infections produce a feeling of repulsion on spectators, the doctor seems to love them to an extraordinary degree. He affirms in this sequence: "you are so beautiful, my baron. Your skin, love to me". Another hint of homosexual behaviour is the baron's predilection for physical contact. Immediately after the above mentioned sequence, we get another one in which the baron kills an androgynouslooking Harkonnen. This violent act is not, however, perceived as malevolent or sadistic but rather as a sensual one, if we take into account the baron's behaviour. When he is approaching this young Harkonnen, it is as if he were to kiss him, and the pleasure that the killing process offers him could be interpreted as an erotic act, which culminates with the baron being fully covered by the blood of this Harkonnen.

Another visual example of this lack of traditional masculine traits can be seen in a sequence where one of the most important members of the Harkonnen - Feyd Rautha (Sting) -is seen half-naked in bright blue underwear and covered by steam. The baron talks to him using a sensual voice and whispers: "lovely Feyd". All of a sudden, he recovers his usual demanding tone and asks about his doctor. Moreover, we notice the baron's polished nails —of the colour of blood — throughout the whole film. These elements that reinforce sensuality are, then, linked in a way to homosexuality, and emphasised by the fact that the Harkonnen inhabit a space where only male figures are found.

Homosexual behaviour pervades, then, this planet, where its inhabitants stand for what Nochimson denominates "a mutilated masculinity" (Nochimson 1997: 128). The mutilation of masculinity in this race becomes an enormous threat, not for the members of Giedi Prime, but for the rest of the "Known Universe", especially for the Atreides family

\footnotetext{
7 This idea of masculinity is intricately connected with men's physical strength, and as Segal affirms: "the contemporary guardians of true manhood still believe that living one's life as a man involves toughness, struggle and conquest" (Segal 1997: 104). Many critics agree that the existence of a fixed pattern of masculinity has always worked, and is still alive in many different societies. Thus, Badinter associates this model of masculinity with "the tough guy", defined by her as a "sexual animal with women, but who does not become attached to any woman; a creature who meets his male counterparts only in competition, war, or sports" (Badinter 1995: 130). This male ideal was adapted by different cultures, but the US especially imposed and universalised its own images of virility, mainly through its representations on screen.
}

Odisea, $n^{\circ} 6$, ISSN $1578-3820,2005,43-54$ 
and the Fremen. The menacing nature of the Harkonnen is then stressed, forcing spectators to associate them with the figure of the enemy.

Baron Vladimir Harkonnen stands for the main representation of the enemy. The negative characterisation of the enemy has always been a constant motif in many films and in different genres. Thus, in westerns we found the figure of the villain or rioter whose appearance was sinister, and his traits clearly delineated from the beginning of the film, as were the gangster's or the criminal's in detective and action films respectively, to name just a few. In SF, the enemy has constantly been represented as non-human, dangerous and destructive, as were all the monsters, aliens, beasts, or menacing androids found in many films, especially in the earliest representations of the genre. The baron is depicted from his first appearance on screen as a deformed character both physically and in his malevolent personality. His physical attributes are linked to notions of disgust and abjection ${ }^{8}$.

The abject attributes that define the Baron are seen in his external appearance, especially when we get close-ups of his deformed face, covered by sweat, blood, and skin infections. He also has, like the rest of the Harkonnen race, red hair, a typical feature exploited in fairy tales and associated with the villain.

This association of the Harkonnen race with the enemy, together with these characters' predilection for blood and their previously mentioned homosexual tendencies contribute to connect this fictional space with menacing diseases. During the 80s, newly discovered infectious diseases caused a general feeling of insecurity in US society. Hence, the film's insistence on the threatening aspects of the inhabitants of this planet aims at reflecting this popularised anxiety concerning gender relations in the 80 s in a very explicit way.

Giedi Prime stands, then, for an unusual planet in the sense that its inhabitants do not follow a conventional behaviour concerning gender relations, and they represent a social threat for the rest of the Known Universe. These challenging gender traits are then condemned by linking them to the abject, the disgusting and the menacing.

\section{CALADAN: THE FATHER-SON LEGACY}

In opposition to Giedi Prime, in the watery planet Caladan, gender relations are far more conventional and based on patriarchal notions. The dominance of the planet is achieved by the figures of Duke Leto and his son, Paul, who takes over all his father's responsibilities once he is assassinated. The father-son relationship reinforces patriarchy or "male dominance" (Britton 1986: 24) and is, at the same time, a repetitive structure in popular films of the Reagan era. Andrew Britton in his well-known article "Bliss Out" points out this fact and argues that patriarchy "is very much the term to describe what gets reaffirmed in Reaganite entertainment: with unremitting insistence and stridence, it is the status and function of the father and their inheritance by the son that are at stake" (Britton 1986: 24).

\footnotetext{
8 Kristeva takes up Lacan's psychoanalytic theory and rereads it from a feminist point of view, introducing the concept "abject", which, according to her, "confronts us with our earliest attempts to release the hold of maternal entity even before existing outside of her, thanks to the anatomy of language" (Kristeva 1982: 13). Thus, the abject if formed before the acquisition of language, being the object of our primal rejection. This first rejection, she argues, remains in the unconscious as it cannot be assimilated. The monster figure is, therefore, the replacement of this fear or phobia.
} 
Father-son relationships are crucial, then, for most films that came out at that time. Susan Jeffords in Hard Bodies analyses some of the most popular narratives of the 80s based on this bond, as it is the case of the Star Wars trilogy, Indiana Jones and the Temple of Doom (1984), Indiana Jones and the Last Crusade (1989), the Back to the Future films, or the three parts of Rambo. The continuity from one generation to another and the tension that sometimes these characters establish between them - like Skywalker and his father Darth Vader - portray, Jeffords claims, the American anxieties for the cultural dynamic taking place at that time, that is, the continuity or not of the Reagan Revolution.

In Dune the relationship between Leto and Paul is a key element for narrative development, since the plot line would be altered if their bond was not so close. They both worry about each other and show constant signs of mutual respect. When Paul feels his father is in danger, he worries about him and looks hurt. Paul himself is the consequence of his father's wishes for a son, and his birth implies the break of the rule that Lady Jessica's sisterhood established, by which only the conception of daughters was permitted. This fact guarantees, in a way, the closeness of their future bond and eliminates, therefore, the tension that some father-son relationships offered. The main goal of Paul's actions towards the Harkonnen race is to take revenge on his father's assassination, which he promises to fulfil once he knows the truth about Leto's tragic destiny.

Power and dominance are transmitted from the father figure to his descendant, emphasising, thus, patriarchal bonds. Therefore, when Leto is killed, Paul replaces him, assuming not only the condition of the main and most powerful representative of the planet, but also protecting his mother, Lady Jessica. Paul's concern with her begins when Leto dies, and mother and son crash into the deserted planet Arrakis. He takes care of her mother in the same way as his father would have done if alive and soon he becomes the leader and the visible head of Caladan society and politics, in the same way as his father did.

Yet it is from these sequences in the desert onwards when it is observed an intimate and close relationship between Paul and Jessica, which goes further from the one Paul had with his father. His mother becomes indispensable for him and without her assistance, Paul would not have achieved his messianic role within the new planet.

The proximity towards his mother is achieved in great part by means of Paul's dreams, which insist in her most intimate and feminine spheres. Nochimson points out this fact when she affirms at one point that "the waking dreams bring Paul closer to his larger identity as they bring him closer to the feminine" (Nochimson 1997: 131). This is particularly true, she claims, in his third dream, once they have crashed into the desert. He envisions the inside of his mother's womb in detail, and gets to know that she is pregnant, anticipating, thus, the birth of his sister Alia (Alicia Roanne Witt).

The film's insistence on Paul's continuous dreams and deep thoughts reinforces his link with the feminine, something that, together with his unconventional look, suggests his bond with women.

In short, it can be affirmed that in this planet family values are clearly stressed, following in this way the general tendency in many films of this period and their conservative overtones. We are presented with relationships that, although still marked by patriarchy, 
are harmonious and based on love. Paul, Jessica and Leto show respect for each other and are depicted as a happy family. Moreover, the hero's occasional link with feminine aspects constitutes a novelty and is expressed through his dreams, which constitute a typical Lynchian topic 9 .

\section{THE EMPIRE: THE CARICATURE OF PATRIARCHY}

The most striking feature about gender relations in the home of the Emperor is the exaggerated insistence of the film in asserting Shaddam IV's unquestionable superiority. This male figure is constantly linked with power, authority and wealth, which hints at the 80 s generalised insistence on reasserting conservative values and its progressive interest in material possessions and consuming.

This is to be seen in all the elements of the mise-èn-scene, especially in the setting. From the very beginning of the film, we find a court covered in gold and designed with impressive architectural structures, which suggest the grandiosity and importance of its main representative, the Emperor. A big and unusual golden structure circles a throne, where the Emperor sits proudly, and becomes the object of all the looks - both of the spectators' and characters'. Costume also helps to this exaltation of the figure of the Emperor. All the members of this court are over-dressed with exuberant gold accessories, which remind us of those of the ancient Spanish court. Moreover, the characters' behaviour contributes to the reinforcement of the Emperor's power, as they all submit to his orders and wishes. Reverend Mother Gaius Helen Mohian is asked by him to leave the room when she first appears. She does so immediately, saying "yes my lord", her submissiveness reinforcing the Emperor's rank and authority.

Apart from this, technical aspects also contribute to emphasise this exaggerated characterization of the Emperor. He stands normally at the centre of the frame, and in between the different sequences we frequently get "establishing shots"10, which help spectators not to forget about the impressive look of this court. After the establishing shots we normally get medium shots of the Emperor's figure, creating a link between the magnificence and opulence of the court and Shaddam IV.

This over-exaltation of the male figure's power is almost near the absurd and caricature. Nochimson refers to this fact as the "carnivalized look of the Empire" (Nochimson 1997: 128). Moreover, this insistence on male supremacy contrasts with the "unstressed" power of women within this planet. The Bene Gesserit sisterhood, who supports and helps the Emperor at every moment, is, in fact, the key element for the Empire's superior condition over the rest of the Known Universe. Thanks to these women's special use of the voice and other gifts, the Emperor is considered the unquestionable ruler of the universe. He shows

\footnotetext{
${ }^{9}$ Lynch's use of the cinematic vocabulary, full of visual and aural images, is constant in his whole production, and suggests that "once we understand that we ourselves have created cultural forms and that they only have the meaning we give them, we are free to understand the forces in the universe that are truly larger than we are and how they connect us to a greater reality" (Nochimson 1997: 4).

${ }^{10}$ Bordwell and Thompson define "establishing shot" as "[a] shot, usually involving a distant framing, that shows the spatial relations among the important figures, objects, and setting in a scene" (Bordwell \& Thompson 1997: 478).
} 
the need of these special gifts right at the beginning of the film, when he asks his "truthsayer", Reverend Mother, to use her powers for his own interests.

In short, the Empire's insistence on patriarchal values clashes with its consequent negation of the male figure's authority by means of the exaggeration and caricature of its main representative, the Emperor. The repressed power of women in this planet also contributes to this parody.

\section{ARRAKIS OR DUNE: A NEUTRAL PLACE FOR GENDER RELATIONS}

Paradoxically, it is in the deserted and arid planet Dune where gender relations between men and women are established on a more equal basis. However, the benefits of this neutrality are not clearly exposed. The inhabitants of this planet - the Fremen- are genderequal beings who share questionable ethics (they drink the blood of their dead in order to survive) and live in a mysterious and unexplored planet with huge worms. The setting is, therefore, especially significant here as it makes us connect this unknown planet to new possibilities for gender relations. This hits at the sexual revolution that was taking place at the time and the 80 s conscience of the existence of unexplored gender relations based on neutrality and equality.

The Fremen are seen as a people who do not follow any hierarchical structure, except for the importance of their leader, Stilgar (Kenneth McMillan) and his daughter, Chani (Sean Young). Stilgar's superiority resides, nevertheless, in that he is a bit stronger than the rest of his "tribe". In fact, all members in this community agree on accepting Paul as their ultimate advisor and "messiah".

Male and female Fremen share the same lifestyle and fulfil equal functions. We see, for example, young Chani fighting against their common enemy, the Harkonnen. Fighting and the use of military weapons have traditionally denoted typical male activities, and it is not until the 90s when "virilised heroines" are seen on screen, fighting and displaying their powerful bodies. The Fremen race offers in this sense an equality between the sexes, which is visually reinforced by the fact that they all wear the same costume - a special black rubber suit - and that they all have, due to effect of water, deep blue eyes.

Thus, the visual non-differentiation of the sexes anticipates postmodern concerns about dissolution of frontiers and gender closeness. Yet this equality is not totally achieved if we take into account the fact that Paul gets endless power within this tribe and becomes its messiah and saviour. Moreover, this society is settled in an unexplored desert where many dangers may be found. Gender equality is perceived then as something possible but still hazardous.

\section{CONCLUSION}

In short, gender relations represented in the four different planets portray the many concerns of American society in the 1980s. They go from the depiction of non-conventional, and therefore, threatening relationships among the Harkonnen members (which hints at homosexuality), to the exaggerated insistence of patriarchy seen in the Emperor's House, resulting in its parody. 
Gender patterns vary a lot depending on the physical space in which the characters are placed. Giedi Prime is a filthy planet inhabited by men who suggest homosexual relationships among them. The tension arises if we consider that it is precisely this society what is considered as the enemy, in so far as it threatens conventional societies, namely Caladan. It is within the Atreides, in spite of the unconventional look of the hero, where patriarchal conventions are better represented. Moreover, the triumph of the hero at the end means the superiority of this house over the rest. The deserted planet Arrakis, however, becomes the battleground and its inhabitants offer more flexible gender relations. This is clearly opposed to the Empire, where the supremacy of the male authority is constantly exalted, resulting in caricature.

Yet, the tension gender relations offers goes further if we consider that within the different planets we also find contradiction. In the Empire, to give an example, there is a clash between the unquestionable superiority of the male figure and the unstressed power of the Bene Gesserit, which is in fact, the real source for the Emperor's notability. It is in the hero characterisation where this tension is better represented. Paul Atreides, despite his embodiment of patriarchal values, is physically different from the heroes of the time and this is reinforced by different technical devices. In this sense, he could be considered the anticipation of the "new hero", who will pervade the 90s.

Lastly, the close bond between cinema and society is suggested in the film and thus the 80s attitude towards gender relations is hinted in it. Despite the film's distant setting and its sometimes grotesque characters, it still reflects faithfully most of the Reagan Era's concerns — patriotism, conquering aims and militarism — as well as social issues and anxieties such as AIDS.

\section{REFERENCES}

Badinter, E. 1995. XY. On Masculine Identity. New York: Columbia Press.

Bordwell, D. \& K. Thompson. 1997. Film Art: An Introduction. New York: Mac Graw Hill.

Britton, A. 1986. "Blissing Out: The Politics of Reaganite Entertainment". Movie 31/ 32: $1-36$.

Brode, D. 1990. The Films Of the Eighties. New York: Citadel Press Book.

ButLer, J. 1990. Gender Trouble: Feminism and the Subversion of Identity. New York: Routledge. Routledge.

Carabí, A. 2000. “Construyendo nuevas humanidades: Una introducción”. Nuevas humanidades. Eds. M. Segarra y A. Carabí. Barcelona: Icaria, 15-27.

De Lauretis, T. 1987. Technologies of Gender. Essays on Theory, Film and Fiction. Bloomington: Indiana University Press. 
JefFords, S. 1994. Hard Bodies. Hollywood Masculinity in the Reagan Era. New Brunswick: Rutgers University Press.

Kristeva, J. 1982. Powers of Horror: An Essay on Abjection. New York: Columbia University Press.

Nochimson, M. 1997. The Passion of David Lynch: Wild at Heart in Hollywood. Austin: University of Texas Press.

Ortner, S. 1995. “Is Female to Male as Nature to Culture?". A Cultural Studies Reader. History, Theory, Practice. Eds. J. Munns \& G. Rajan. London: Longman, 491-508.

PeAch, L.J. 1998. Women in Culture. A Women's Studies Anthology. Malden Mass: Blackwell.

Segal, L. 1997. Slow Motion: Changing Masculinities, Changing Men. London: Routledge. 